\title{
Evaluation and updating of the Medical Malacology Collection (Fiocruz-CMM) using molecular taxonomy
}

\author{
Cryslaine Aguiar-Silva', Cristiane Lafetá Furtado Mendonça ${ }^{1,2}$, Pedro Henrique da Cunha Kellis Pinheiro ${ }^{1}$,
} Silvia Gonçalves Mesquita ${ }^{1}$, Omar dos Santos Carvalho ${ }^{1}$ and Roberta Lima Caldeira ${ }^{1 *}$

\begin{abstract}
Background: The Medical Malacology Collection (Coleção de Malacologia Médica, Fiocruz-CMM) is a depository of medically relevant mollusks, especially from the genus Biomphalaria, which includes the hosts of Schistosoma mansoni. Taxonomic studies of these snails have traditionally focused on the morphology of the reproductive system. However, determination of some species is complicated by the similarity shown by these characters. Molecular techniques have been used to try to overcome this problem.

Description: The Fiocruz-CMM utilizes morphological and/or molecular method for species' identification. However, part of the collection has not been identified by molecular techniques and some points were unidentified. The present study employs polymerase chain reaction-based analysis of restriction fragment length polymorphisms (PCR-RFLP) to evaluate the identification of Biomphalaria in the Fiocruz-CMM, correct existing errors, assess the suitability of taxonomic synonyms, and identify unknown specimens. The results indicated that $56.7 \%$ of the mollusk specimens were correctly identified, $4.0 \%$ were wrongly identified, and $0.4 \%$ was identified under taxonomic synonyms. Additionally, the PCR-RFLP analysis identified for the first time $17.6 \%$ of the specimens in the Collection. However, $3.1 \%$ of the specimens could not be identified because the mollusk tissues were degraded, and $18.2 \%$ of the specimens were inconclusively identified, demonstrating the need for new taxonomic studies in this group.

Conclusion: The data was utilized to update data of Environmental Information Reference Center (CRIA). These studies demonstrate the importance of using more than one technique in taxonomic confirmation and the good preservation of specimens' collection.
\end{abstract}

Keywords: Zoological collection; Biomphalaria; PCR-RFLP; Morphological identification; Molecular taxonomy

\section{Introduction}

The Medical Malacology Collection (Coleção de Malacologia Médica, Fiocruz-CMM) located in the Medical Helminthology and Malacology Laboratory (Laboratório de Helmintologia e Malacologia Médica, LHMM) of the René Rachou Research Center (Centro de Pesquisas René Rachou, CPqRR/Fiocruz) comprises approximately 12,000 mollusk specimens with medical or veterinary relevance. The collection consists mainly of representatives of the genus Biomphalaria (Preston, 1910). This

\footnotetext{
* Correspondence: caldeira@cpqrr.fiocruz.br

'Laboratório de Helmintologia e Malacologia Médica do Centro de Pesquisas René Rachou-Fiocruz, Av. Augusto de Lima 1715, Belo Horizonte, MG 30190-002, Brasil

Full list of author information is available at the end of the article
}

genus includes the intermediate hosts of the trematode Schistosoma mansoni Sambon, 1907, a causative agent of intestinal schistosomiasis.

This collection was initiated in 1993, when the LHMM began to receive mollusk specimens from various locations for morphological species identification and evaluation of trematode infection. The Fiocruz-CMM has specimens from Germany, France, Argentina, Bolivia, Brazil, Chile, Colombia, Costa Rica, Cuba, Ecuador, Mexico, Paraguay, Dominican Republic, Uruguay and Venezuela. Upon arriving at LHMM, mollusks of the genus Biomphalaria are examined to verify the presence of S. mansoni cercariae, and five samples of each collection point are anesthetized and sacrificed. Their shells and

\section{它}


body are separated, and fragments from the cephalopodal region are cryopreserved (for molecular studies). This material is later encoded and routed to Fiocruz-CMM.

Classical species identification involves on comparison of morphological characters of the shell (such as diameter, width and number of whorls), and male and female reproductive organs, as described by Paraense (1975, 1981, 1984, 1988, 1990), Paraense and Deslandes (1958a, 1958b), Paraense et al. (1992), and Estrada et al. (2005). However, identification can be hindered by interspecific morphological similarities in these characters, the small size of some specimens, and inadequate processes (Paraense 1975; Caldeira et al. 1998; Spatz et al. 1999). During the early 2000's, therefore, the LHMM began to use molecular tools to aid in the identification of these mollusks. Currently, polymerase chain reactionbased analysis of restriction fragment length polymorphisms (PCR-RFLP) within the internal transcribed spacer (ITS) of the ribosomal RNA gene is used to distinguish Biomphalaria species, as defined by Vidigal et al. (2000a) and Teodoro et al. (2010).

However, part of the mollusks of the Fiocruz-CMM collection has not been characterized using molecular techniques, and some deposited specimens remain unidentified. Thus, the objective of this study was to evaluate and update the identification of Biomphalaria specimens in the Fiocruz-CMM collection using molecular taxonomic techniques. Unidentified specimens were analyzed using morphological and molecular techniques; specimens that had been identified using only morphological traits were confirmed or corrected; and the resulting taxonomic data were updated and made available to users of the collection.

\section{Methodology}

\section{Specimen selection}

Collection points deposited between 1993 and 2011 that included Biomphalaria specimens were selected. There were 1,398 such collection points. Specimens from 198 of these collection points had already been identified by PCR-RFLP and were not included in this study. Thus, at least one specimen from each of 1,200 collection points was analyzed using morphological traits and/or PCRRFLP.

\section{Morphological identification}

The mollusks were dissected according to the procedures of Deslandes (1951) and identified based on the morphology of their shells, reproductive and excretory organs (Paraense 1966a, 1975, 1981, 1984, 1988, 1990; Paraense and Deslandes 1958a, 1958b; Estrada et al. 2005). The dissected specimens were returned to the collection for further morphological studies.

\section{Molecular techniques}

From the samples selected for molecular identification, the fragments from the cephalopodal region that were cryopreserved were divided into two parts. One part was retained in cryopreservation, and the other part was used for DNA extraction. Total DNA was extracted using the Wizard kit (Promega) according to the manufacturer's instructions. The PCR-RFLP technique was performed according to the methods of Vidigal et al. (1998). For species identification, the resulting profiles were compared to those obtained by Spatz et al. (1999), Vidigal et al. (2000a), Caldeira et al. (2000), Vidigal et al. (2001) and Teodoro et al. (2010).

\section{Table 1 Number (and percentage) of collection points with identified specimens of each Biomphalaria morphotype before (initial) and after this study (final)}

\begin{tabular}{|c|c|c|}
\hline Morphotype & $\begin{array}{l}\text { Initial collection } \\
\text { points }(\%)\end{array}$ & $\begin{array}{l}\text { Final collection } \\
\text { points }(\%)\end{array}$ \\
\hline Biomphalaria amazonica Paraense 1966a & $9(0.7)$ & $7(0.6)$ \\
\hline Biomphalaria cousini Paraense 1966b & $4(0.3)$ & $4(0.3)$ \\
\hline Biomphalaria edisoni Estrada et al., 2006 & $2(0.2)$ & $2(0.2)$ \\
\hline Biomphalaria glabrata (Say, 1818) & $331(27.6)$ & $382(31.8)$ \\
\hline Biomphalaria havanensis (Pfeiffer, 1839) & $6(0.5)$ & $20(1.7)$ \\
\hline $\begin{array}{l}\text { Biomphalaria intermedia Paraense \& } \\
\text { Deslandes, } 1962\end{array}$ & $21(1.75)$ & $40(3.3)$ \\
\hline Biomphalaria kuhniana (Clessin, 1883) & $19(1.6)$ & $23(1.9)$ \\
\hline Biomphalaria obstructa (Morelet, 1849) & $4(0.3)$ & - \\
\hline Biomphalaria occidentalis Paraense, 1981 & $23(1.9)$ & $30(2.5)$ \\
\hline Biomphalaria oligoza Paraense, 1974 & $3(0.2)$ & $10(0.8)$ \\
\hline Biomphalaria orbignyi Paraense, 1975 & - & $1(0.1)$ \\
\hline Biomphalaria peregrina (Orbigny, 1835) & $116(9.7)$ & $208(17.3)$ \\
\hline Biomphalaria prona (Martens, 1873) & $6(0.5)$ & $6(0.5)$ \\
\hline Biomphalaria schrammi (Crosse, 1864) & $14(1.2)$ & $20(1.7)$ \\
\hline Biomphalaria aff. straminea ${ }^{b}$ & - & $4(0.3)$ \\
\hline Biomphalaria straminea (Dunker, 1848) & $198(16.5)$ & $266(22.2)$ \\
\hline Biomphalaria tenagophila (Argentina) ${ }^{c}$ & - & $6(0.5)$ \\
\hline $\begin{array}{l}\text { Biomphalaria tenagophila } \\
\text { (Orbigny, 1835) }\end{array}$ & $96(8)$ & $111(9.2)$ \\
\hline $\begin{array}{l}\text { Biomphalaria temascalensis } \\
\text { (Rangel-Ruiz, 1987) }^{\mathrm{a}}\end{array}$ & $1(0.1)$ & - \\
\hline $\begin{array}{l}\text { Biomphalaria tenagophila guaibensis } \\
\text { Paraense, } 1984\end{array}$ & $14(1.2)$ & $23(1.9)$ \\
\hline Unidentified & $333(27.8)$ & $37(3.1)$ \\
\hline Total & $1,200(100)$ & $1,200(100)$ \\
\hline
\end{tabular}

Junior synonym of Biomphalaria havanensis.

${ }^{\mathrm{b}}$ Specimens morphologically similar to Biomphalaria straminea and originating from Espinillar, Uruguay, the type locality of Biomphalaria aff. straminea. 'Specimens morphologically identical to Biomphalaria tenagophila but with a distinct molecular profile. 


\section{Analysis and update of the collection database}

The specimens were grouped into six categories: 1) correctly identified, 2) erroneously identified, 3) identified under taxonomic synonyms, 4) inconclusively identified, 5) unidentified due to tissue degradation, and 6) newly identified (specimens that had been deposited unidentified).

\section{Results}

\section{Selected mollusks}

The Fiocruz-CMM collection included 20 Biomphalaria morphotypes obtained from 1,200 collection points (Table 1).

\section{Taxonomic analyses}

Among the 1,200 analyzed collection points, the species identifications were 1 ) correct for $56.7 \%$ of the specimens, 2 ) erroneous for $4.0 \%, 3$ ) synonymous for $0.4 \%$ (these specimens were identified as $B$. obstructa and B. temascalensis, junior synonyms of $B$. havanensis), 4) inconclusive for $18.2 \%, 5$ ) undetermined due to tissue degradation for $3.1 \%$, and 6) newly determined for $17.6 \%$, including one specimen of $B$. orbignyi. The inconclusively identified and

Table 2 Erroneous species identifications among the analyzed collection points

\begin{tabular}{ccc}
\hline Previous identification & Current identification & $\begin{array}{c}\text { No. of collection } \\
\text { points with } \\
\text { each error }\end{array}$ \\
\hline Biomphalaria tenagophila & Biomphalaria peregrina & 10 \\
Biomphalaria tenagophila & Biomphalaria glabrata & 8 \\
Biomphalaria straminea & Biomphalaria kuhniana & 5 \\
Biomphalaria peregrina & Biomphalaria tenagophila & 4 \\
Biomphalaria amazonica & Biomphalaria cousini & 2 \\
Biomphalaria tenagophila & Biomphalaria occidentalis & 2 \\
Biomphalaria glabrata & Biomphalaria tenagophila & 2 \\
Biomphalaria glabrata & Biomphalaria straminea & 2 \\
Biomphalaria intermedia & Biomphalaria peregrina & 1 \\
Biomphalaria intermedia & Biomphalaria straminea & 1 \\
Biomphalaria occidentalis & Biomphalaria tenagophila & 1 \\
Biomphalaria peregrina & Biomphalaria intermedia & 1 \\
Biomphalaria peregrina & Biomphalaria straminea & 1 \\
Biomphalaria prona & Biomphalaria kuhniana & 1 \\
Biomphalaria schrammi & Biomphalaria peregrina & 1 \\
Biomphalaria straminea & Biomphalaria intermedia & 1 \\
Biomphalaria straminea & Biomphalaria glabrata & 1 \\
Biomphalaria straminea & Biomphalaria occidentalis & 1 \\
Biomphalaria straminea & Biomphalaria oligoza & 1 \\
Biomphalaria tenagophila & Biomphalaria straminea & 1 \\
Biomphalaria tenagophila & Biomphalaria tenagophila & 1 \\
Total number of collection points with errors & 48 \\
\hline & & 1 \\
\hline
\end{tabular}

degraded specimens were retained in the collection for further evaluation.

The confirmed, corrected, synonymized and newly determined species identifications were updated in the collection registry and in the Environmental Information Reference Center (Centro de Referência em Informação Ambiental, CRIA) database (http://splink.cria.org.br).

Table 2 lists the erroneous species identifications that were found in the Fiocruz-CMM collection. Nearly half of the erroneous identifications were originally identified as B.tenagophila.

Three groups were prominent among the inconclusively identified specimens. 1) Specimens from the provinces of Corrientes, Argentina and Espinillar, Uruguay (four collection points) were morphologically similar to $B$. straminea, but their restriction profile for the enzyme DdeI differed from that of $B$. straminea (which had been previously established), here represented by sample from Minas Gerais, Brazil (Figure 1). 2) Specimens from the provinces of Corrientes, Argentina and Espinillar, Uruguay (six collection points) were morphologically similar to $B$. tenagophila from Brazil, but their restriction profiles for the enzymes DdeI and AluI were similar to those of B. t. guaibensis from Rio Grande do Sul, Brazil (Figure 1). 3) Specimens from 208 collection points in various Brazilian states were morphologically identified as B. peregrina, but although some of these specimens had molecular profiles characteristic of that species, others had the molecular profile of $B$. oligoza (which had been previously established), here represented by sample from Rio Grande do Sul, Brazil (Figure 2). In an attempt to clarify the identity of these specimens, a portion of the mitochondrial cytochrome c oxidase subunit I (COI) gene was amplified by PCR, and the restriction enzymes ClaI, RsaI, and AluI were used to generate PCR-RFLP profiles. There was no restriction site for the enzymes ClaI and RsaI. For AluI, the specimens morphologically identified as $B$. peregrina sometimes showed $B$. peregrina profiles and sometimes showed B. oligoza profiles (data not shown).

\section{Discussion}

The Fiocruz-CMM collection contains taxonomic groups of medical or veterinary relevance to aid in the control of schistosomiasis, support research, and contribute to human-resources development. Considering the global mobilization, consolidation, institutionalization, and organization of biological collections, studies evaluating the taxonomic accuracy of such collections are broadly relevant (Godfray and Knapp 2004; Egler and Santos 2006). The morphological identification of Biomphalaria species is challenging (Paraense 1988; Paraense et al. 1992), and PCR-RFLP has been used to aid in species identification (Spatz et al. 1999; Vidigal et al. 2000a; Caldeira et al. 2000; 


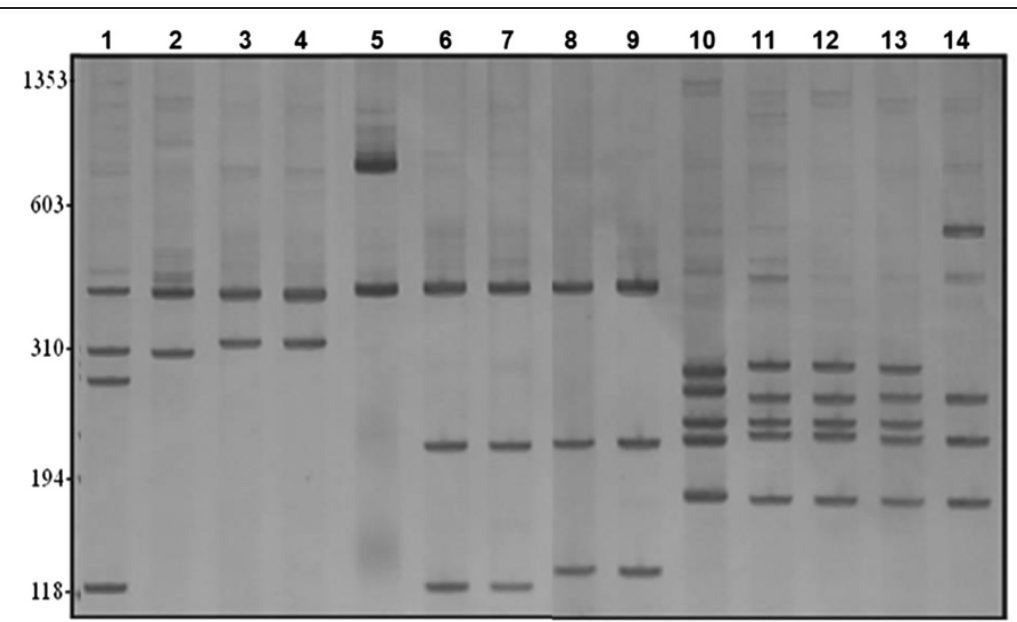

Figure 1 Biomphalaria restriction profiles: $6 \%$ polyacrylamide gel showing the PCR-RFLP profiles obtained by digesting the rDNA ITS region of Biomphalaria mollusks with Ddel (lanes 1-9) and Alul (lanes 10-14). Lane 1: Biomphalaria straminea (Minas Gerais, Brazil); 2 : Biomphalaria intermedia (Minas Gerais, Brazil); 3: Biomphalaria straminea (Corrientes, Argentina); 4: Biomphalaria straminea (Espinillar, Uruguay); 5: Biomphalaria tenagophila (Minas Gerais, Brazil); 6-7: Biomphalaria tenagophila (Corrientes, Argentina); 8: Biomphalaria tenagophila guaibensis (Rio Grande do Sul, Brazil); 9: Biomphalaria occidentalis (Minas Gerais, Brazil); 10: Biomphalaria tenagophila (Minas Gerais, Brazil); 11-12: Biomphalaria tenagophila (Corrientes, Argentina); 13: Biomphalaria tenagophila guaibensis (Rio Grande do Sul, Brazil); 14: Biomphalaria occidentalis (Minas Gerais, Brazil). Values to the left correspond to molecular weights in base pairs (bp).

Carvalho et al. 2004). Thus, both tools were used to the taxonomic accuracy of the Fiocruz-CMM collection.

Initially, 8,831 specimens from 1,398 collection points were selected for this study. Specimens from 333 collection points were unidentified, while specimens from 198 collection points had already received molecular confirmation. Thus, this study evaluated the species

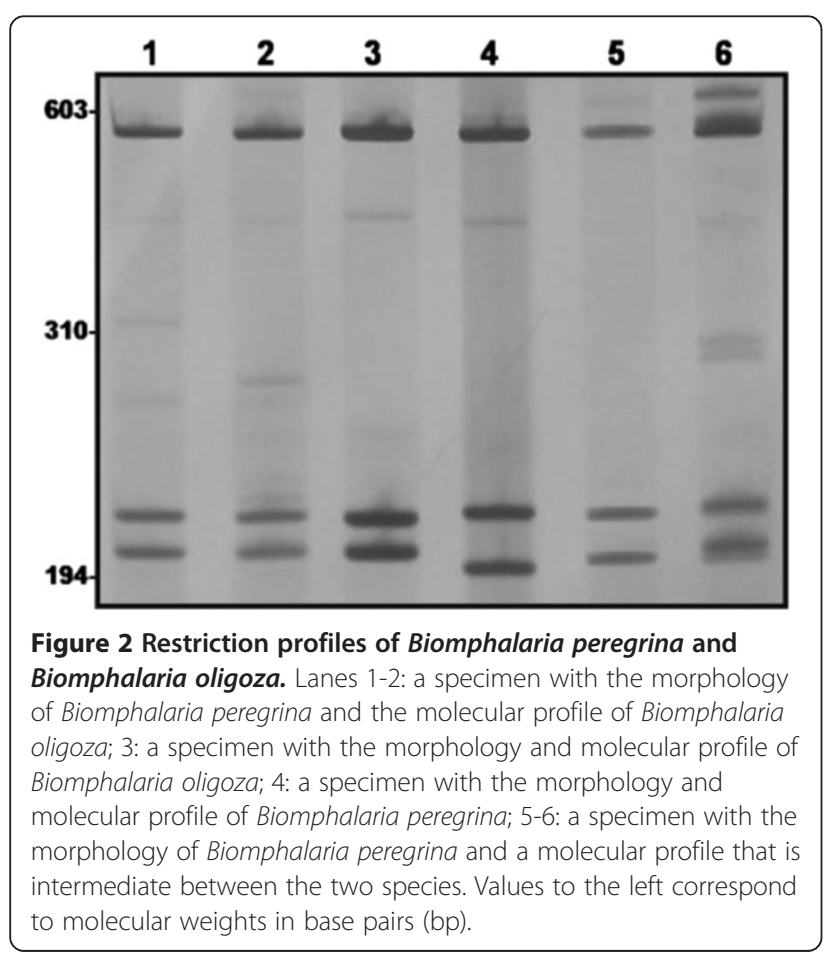

identifications of mollusks from 1,200 collection points deposited at Fiocruz-CMM.

Identification errors occurred mainly between $B$. peregrina and B. tenagophila (29.1\%), due to the similarity of these species' shell and reproductive organs (Paraense 1966a); and between B. tenagophila and B. glabrata (20.8\%), due to the many identical traits of juvenile and sometimes adults B. glabrata and B. tenagophila specimens (Barbosa 1964, Paraense and Deslandes 1959). The frequencies of these errors reflect the proportions of these species in the Fiocruz-CMM. The identification of certain $B$. havanensis specimens as $B$. temascalensis and $B$. obstructa was adequate because Yong et al. (2001) and DeJong et al. (2001) have concluded that these three entities actually form a single species, making $B$. temascalensis and B. obstructa junior synonyms of $B$. havanensis.

Three groups were considered inconclusive: $B$. aff. straminea, B. tenagophila from Argentina, and B. peregrina. Paraense and Corrêa (1989) classified a population from Espinillar, Uruguay, as $B$. aff. straminea due to its similarity to B. straminea. Vidigal et al. (1998) obtained molecular profiles with two bands (470 and $310 \mathrm{bp}$ ) for $B$. straminea populations from the city of San Miguel and the provinces of Chaco and Corrientes, Argentina, and four bands (470, 310, 280, and $120 \mathrm{bp}$ ) for $B$. straminea populations from Brazil. In the present study, specimens from Corrientes, Argentina and Espinillar, Uruguay had profiles with two bands, agreeing with the observations of Vidigal et al. (1998), and were morphologically similar to $B$. straminea. 
Specimens from Argentina that were morphologically identified as B. tenagophila showed a profile with three bands, similar to that reported by Vidigal et al. (1998) for populations from Chaco and Corrientes, Argentina, that were morphologically identified as B. tenagophila. However, LHMM has previously used a profile with two bands to characterize $B$. tenagophila (Vidigal et al. 2000a). Spatz et al. (1999) has observed that B. tenagophila from Argentina exhibits greater phylogenetic proximity to both $B$. occidentalis and $B$. $t$. guaibensis than to B. tenagophila from Brazil. Paraense (1961) found no morphological differences between $B$. tenagophila populations from Corrientes, Argentina (the type locality of the species) and Brazil. Paraense (1961) also confirmed that these populations were conspecific by performing controlled crosses.

Some specimens that were morphologically identified as $B$. peregrina showed the molecular profile of that species, while others showed that of B. oligoza when using AluI to digest either ITS (Figure 2) or COI (data not shown). The morphological separation of $B$. peregrina and $B$. oligoza is primarily based on the number of prostatic diverticula, which ranges from zero to seven in B. oligoza (Paraense 1975) and from eight to twenty-two in $B$. peregrina (Paraense 1966b, 1975). However, the specimens that exhibited the molecular profile of B. oligoza in this study had 10 to 18 diverticula. According to Vidigal et al. (2000b), the phylogenetic positions of these two species are uncertain because $B$. oligoza specimens are always grouped together, but $B$. peregrina specimens are ultimately grouped with $B$. oligoza. Thus, the number of diverticula may not be a definitive trait for the separation of these species.

Further morphological and molecular studies and experimental crosses are needed to establish the phylogenetic relationships among the members of these three groups, specially the specimens from inconclusive group. The part of the Cytochrome c oxidase subunit I gene (cox1) will be sequenced to better understanding of the taxonomic status of these species. This region has been widely used in taxonomic studies an approach termed DNA barcode (Hebert et al. 2003).

Some specimens could not be identified due to tissue degradation resulting from the lack of periodic maintenance. This result highlights the importance of adequately maintaining biological collections (Egler and Santos 2006).

The results of this study confirm the relevance of molecular taxonomic techniques in evaluating and updating the species identifications of Biomphalaria specimens and the need to guarantee proper specimen preservation. Importantly, the consolidation of this collection and the performance of this study were made possible by funding from Fiocruz and the Minas Gerais Research
Foundation (Fundação de Amparo à Pesquisa do Estado de Minas Gerais, Fapemig), confirming the need for financial support to strengthen biological collections.

\section{Competing interests}

The authors declare that they have no competing interests.

\section{Authors' contribution}

CAS made the morphological and molecular analysis of the molluscs, participated in the draft the manuscript. CLF Mendonça participated of the morphological analysis of the molluscs and in the draft the manuscript. PHC Pinheiro helped in the morphological and molecular analysis of the molluscs. SGM made the molecular identification of part of the molluscs. OSC participated in the draft the manuscript RLC made the morphological and molecular analysis of the molluscs, participated in the draft the manuscript. All authors read and approved the final manuscript.

\section{Acknowledgements}

This work was partially supported by grants from the Fapemig and Fiocruz. We would like to thank Tatiana Maria Teodoro, Karen Bernardina Vianini, José Geraldo Amorim da Silva and the students from the Helminthology and Malacology Medical Laboratory of the CPqRR for technical support.

\section{Author details}

${ }^{1}$ Laboratório de Helmintologia e Malacologia Médica do Centro de Pesquisas René Rachou-Fiocruz, Av. Augusto de Lima 1715, Belo Horizonte, MG 30190-002, Brasil. ²Pontifícia Universidade Católica de Minas Gerais, Belo Horizonte, MG, Brasil.

Received: 30 May 2014 Accepted: 1 August 2014

Published: 20 August 2014

\section{References}

Barbosa FS (1964) The renal ridge a disputed feature of the anatomy of the planorbid snail Australorbis tenagophilus. Rev Inst Med Trop 6(2):64-70

Caldeira RL, Vidigal T, Paulinelli ST, Simpson AJG, Carvalho OS (1998) Molecular identification of similar species of the genus Biomphalaria (Mollusca: Planorbidae) determined by a polymerase chain reaction restriction fragment length polymorphism. Mem Inst Oswaldo Cruz 93:219-225

Caldeira RL, Vidigal T, Matinella L, Simpson AJG, Carvalho OS (2000) Identification of planorbids from Venezuela by polymerase chain reaction amplification and restriction fragment length polymorphism of internal transcriber spacer of the RNA ribosomal gene. Mem Inst Oswaldo Cruz 95(2):171-177

Carvalho OS, Cardoso PCM, Lira PM, Rumi A, Roche A, Berne E Muller G, Caldeira $\mathrm{RL}$ (2004) The use of the polymerase chain reaction and restriction fragment length polymorphism technique associated with the classical morphology for characterization of Lymnaea columella, L. viatrix, and L. diaphana (Mollusca: Lymnaeidae). Mem Inst Oswaldo Cruz 99(5):503-507

Centro de Referência em Informação Ambiental Species Link [homepage on the Internet]. Fundação de Amparo à Pesquisa do Estado de São Paulo, São Paulo, http://www.splink.org.br. Accessed 05 Jan 2012

DeJong RJ, Morgan JAT, Paraense WL, Pointier JP, Amarista M, Ayeh-Kumi PFK et al (2001) Evolutionary relationships and biogeography of Biomphalaria (Gastropoda: Planorbidae) with implications regarding its role as host of the human bloodfluke, Schistosoma mansoni. Mol Biol Evol 18(12):2225-2239

Deslandes N (1951) Técnica de dissecação e exame de planorbídeos. Rev Serv Espec Saúde Públ 4:371-382

Egler I, Santos MM (2006) Diretrizes e estratégias para a modernização de coleções biológicas brasileiras e a consolidação de sistemas integrados de informação sobre biodiversidade. MCT/CGEE, Brasília

Estrada VE, Velásquez LE, Caldeira RL, Bejarano EE, Rojas W, Carvalho OS (2005) Phylogenetics of South American Biomphalaria and description of a new species (Gastropoda: Planorbidae). J Molluscan Stud 72:221-228

Godfray HCJ, Knapp S (2004) Taxonomy for the twenty first century. Introduction. Phil Tran R Soc Lond 359:559-569

Hebert PDN, Cywinska A, Ball SL, De Waard JR (2003) Biological identifications through DNA barcodes. Proc R Soc LondB 270:313-322

Paraense WL (1961) The nomenclature of Brazilian planorbids. II. "Australorbis tenagophilus" (Orbigny 1835). Rev Bras Biol 21:343-349

Paraense WL (1966a) "Biomphalaria amazonica" and "B. cousini", two new species of neotropical planorbid molluscs. Rev Bras Biol 26(2):115-126 
Paraense WL (1966b) The synonymy and distribution of "Biomphalaria peregrina" in the tropical region. Rev Brasil Biol 26(3):269-296

Paraense WL (1975) Estado atual da sistemática dos planorbídeos brasileiros. Arquivo Do Museu Nacional Do Rio de Janeiro 55:105-128

Paraense WL (1981) Biomphalaria occidentalis sp. n. from South America (Mollusca Basommathophora Pulmonata. Mem Inst Oswaldo Cruz 76(2):199-211

Paraense WL (1984) Biomphalaria tenagophila guaibensis ssp. N. from southern Brazil and Uruguay (Pulmonata: Planorbidae). I. Morphology. Mem Inst Oswaldo Cruz 79(4):465-469

Paraense WL (1988) Biomphalaria kuhniana (Clessin, 1883), Planorbid Mollusc from South America. Mem Inst Oswaldo Cruz 83(1):1-12

Paraense WL (1990) Biomphalaria obstructa (Morelet, 1849): A study of topotypic specimens (Mollusca: Pulmonata: Planorbidae). Mem Inst Oswaldo Cruz 85(4):391-399

Paraense WL, Corrêa LR (1989) A potential vector of Schistosoma mansoni in Uruguay. Mem Inst Oswaldo Cruz 84(3):281-288

Paraense WL, Deslandes N (1958a) Observations on Taphius havanensis (Pulmonata: Planorbidae). Rev Bras Biol 18:87-91

Paraense WL, Deslandes N (1958b) Observations on Taphius pronus (Martens, 1873) (Pulmonata: Planorbidae). Rev Bras Biol 18:367-373

Paraense WL, Deslandes N (1959) The renal ridge as a reliable character for separating Taphius glabratus from Taphius tenagophilus. Am J Trop Med Hyg 8(4):456-472

Paraense WL, Pointier JP, Delay B, Pernot AF, Incani RN, Balzan C, Chrosciechowski P (1992) Biomphalaria prona (Gastropoda: Planorbidae): morphological and biochemical study. Mem Inst Oswaldo Cruz 87(2):171-179

Spatz L, Vidigal T, Caldeira RL, Neto ED, Cappa SMG, Carvalho OS (1999) Study of Biomphalaria tenagophila tenagophila. B. t. guaibensis and B. occidentalis by polymerase chain reaction amplification and restriction enzyme digestion of the ribosomal RNA intergenic spacer regions. J Molluscan Stud 65:143-149

Teodoro TM, Janotti-Passos LK, Carvalho OS, Caldeira RL (2010) Occurrence of Biomphalaria cousini (Mollusca: Gastropoda) in Brazil and its susceptibility to Schistosoma mansoni (Platyhelminths: Trematoda). Mol Phylogenet Evol 57:144-151

Vidigal THDA, Spatz L, Nunes DN, Simpson AJG, Carvalho OS, Neto ED (1998) Biomphalaria spp: Identification of the Intermediate Snail Hosts of Schistosoma mansoni by Polymerase Chain Reaction Amplification and Restriction Enzyme Digestion of the Ribosomal RNA Gene Intergenic Spacer. Exp Parasitol 89:180-187

Vidigal THDA, Caldeira RL, Simpson AJG, Carvalho OS (2000a) Further studies on the molecular systematics of Biomphalaria snails from Brazil. Mem Inst Oswaldo Cruz 95(1):57-66

Vidigal THDA, Kissinger JC, Caldeira RL, Pires ECR, Monteiro E, Simpson AJG, Carvalho OS (2000b) Phylogenetic relationships among Brazilian Biomphalaria species (Mollusca: Planorbidae) based upon analysis of ribosomal ITS2 sequences. Parasitology 121:611-620

Vidigal THDA, Caldeira RL, Simpson AJG, Carvalho OS (2001) Identification of Biomphalaria havanensis and Biomphalaria obstructa Populations from Cuba Using Polymerase Chain Reaction and Restriction Fragment Length Polymorphism of the Ribosomal RNA Intergenic Spacer. Mem Inst Oswaldo Cruz 96(5):661-665

Yong M, Gutiérrez A, Perera G, Durand P, Pointier JP (2001) The Biomphalaria havanensis Complex (Gastropoda:Planorbidae) in Cuba: a morphological and genetic study. J Mol Stud 67:103-111

doi:10.1186/2193-1801-3-446

Cite this article as: Aguiar-Silva et al:: Evaluation and updating of the Medical Malacology Collection (Fiocruz-CMM) using molecular taxonomy. SpringerPlus 2014 3:446.

\section{Submit your manuscript to a SpringerOpen ${ }^{\odot}$ journal and benefit from:}

- Convenient online submission

- Rigorous peer review

- Immediate publication on acceptance

- Open access: articles freely available online

- High visibility within the field

- Retaining the copyright to your article

Submit your next manuscript at $\gg$ springeropen.com 